\title{
Accident Model for Car on the Road Section of Highlands Region
}

\author{
Sobri Abusini, Lasmini Ambarwati
}

\begin{abstract}
Motorcycles as a mode of transportation its use continues to increase in the Surabaya City. One of the negative impacts is motorcycle accidents to increase. Based on IRSMS data are the involvement of motorcycles in the accidents of $82.6 \%$ $(2,490$ motorcycle accidents out of 3,014 accidents in Surabaya from 2014 - February 2017). This study was conducted to define the variables that provide opportunities for motorcycle accidents. Three approaches are used to determine the variables that provide probability for motorcycle accidents, which are based on socio-economic, movement and behavior characteristics. Logistic regression analysis is used to obtain the variable that has an effect on the probability of motorcycle accident. The results of research, the socio-economic characteristics that provide probabilities for motorcycle accidents that are gender and education. Based on the characteristics of movement, the chance of motorcycle accident is influenced by the frequency of motorcycle usage. While based on behavioral characteristics, preceding habits from the left have an effect on the chance of motorcycle accident.
\end{abstract}

Index Terms-Motorcycle accident, probability, socioeconomic, movement, behavior, logistic regression.

\section{INTRODUCTION}

$\mathrm{T}$ he city of Surabaya is known as the second largest cultural, educational, tourism, maritime, industrial and trade city in Indonesia after DKI Jakarta. Population in Surabaya as a metropolitan city reached 3,016,653 [1]. The population growth in Surabaya also raises the problem of increasing public demand for transportation services to facilitate human activities. The number of motor vehicles by type in Surabaya City from 2014 to 2015 recorded an increase for all types of motor vehicles. This is shown in the catalogue that published by the Surabaya City Government. Based on the catalogue it is seen that the highest increase of motor vehicle ownership is in the type of motorcycle vehicle with total vehicle in 2014 that is $1,566,595$ vehicles and increase in 2015 that is $1,655,891$ vehicles [2]. This is directly proportional to the involvement of motorcycles in the crash of $82.6 \%(2,490$ motorcycle accidents out of a total of 3,014 motor vehicle accidents in Surabaya from 2014 - February 2017). This suggests that motorcycles are the most vulnerable

A. Abusini is with the Department of Mathecmatics, Nature Science Faculty, Brawijaya University, Malang, East Java, Indonesia (e-mail: abusini@ub.ac.id).

L.Ambarwati is with the Department of Civil Engineering, Engineering Faculty, Brawijaya University, Malang, East Java, Indonesia (e-mail: lasmini@ub.ac.id). vehicle types to accidents.

The use of motorcycles as a mode of transportation has become a favorite or even a lifestyle in many developing countries such as Indonesia. This is because motorcycles are easy to use in towns for close proximity such as between home and workplace. Motorcycles are considered to meet the needs of the middle-class economy down, in addition to the advantages in the ability to maneuver on the side-lines of congestion. Motorcycles also provide efficiency in travel costs. Local traffic accident research based in Surabaya city is very important because the increasing number of motor vehicles in a city that is not balanced with awareness rising and discipline for traffic will further aggravate the existing transportation problems. Accidents involving motorcycles in the Surabaya city account for $82.6 \%$ of accidents that occur, so the identification of motorcycle accident characteristics as well as developing an effective action program in reducing the rate of motorcycle accidents is a strategic and useful step to optimize the performance of road traffic safety better. By modeling the chance of accidents involving motorcyclists based on the function of this road is expected to be used for consideration in decision-making related traffic safety issues in the study area. It is expected that with this modeling the level of traffic safety in the city of Surabaya increases and cases of accidents that occur in the study area may decrease and can be known the main factor cause.

\section{RESEARCH METHODS}

\section{A. Study location, population, and sample}

The location used for this research is Surabaya, East Java. The main targets (respondents) of the questionnaires were motorcyclists who rode on motorbikes and non-motorcycle lanes on arterial, collector and local roads in Surabaya City. The location of the selected study was determined based on the consideration that the location is a public place, where many motorcyclists are the main respondents, and the location has a high accident rate before.

The population used in this study is all motorcyclists in the city of Surabaya or in the study area. Determination of the number of samples in this study using the linear formula time function due to the number of population to be used is not known for certain. A total of 200 respondents were included in this study as a sample [3]. 


\begin{tabular}{clcc}
\multicolumn{4}{c}{$\begin{array}{c}\text { TABLE I } \\
\text { STUDY LOCATION }\end{array}$} \\
\cline { 3 - 4 } No & \multicolumn{2}{c}{ Name of Road } & \multicolumn{2}{c}{ Number of } \\
\cline { 3 - 4 } & & Accidents & MC Accidents \\
\hline \hline 1 & Ahmad Yani & 15 & 79 \\
2 & Arjuna & 35 & 13 \\
3 & Raya Darmo & 14 & 29 \\
4 & Demak & 38 & 11 \\
5 & Diponegoro & 45 & 32 \\
6 & Ir. H. Soekarno & 13 & 38 \\
7 & Gunung Sari & 12 & 11 \\
8 & Jagir Wonokromo & 16 & 9 \\
9 & Jemursari & 15 & 14 \\
10 & Kedung Cowek & 48 & 13 \\
11 & Kenjeran & 10 & 40 \\
12 & Kertajaya & 10 & 8 \\
13 & Kusuma Bangsa & 69 & 9 \\
14 & Raya Mastrip & 19 & 57 \\
15 & Mayjend Sungkono & 10 & 15 \\
16 & Menganti & 20 & 8 \\
17 & Raya Ngagel & 10 & 17 \\
18 & Ngagel Jaya Selatan & 10 & 8 \\
19 & Pakal SBY & 13 & 11 \\
20 & Raya Wonokromo & 10 & 8 \\
21 & Suko Manunggal & 13 & 10 \\
22 & Sememi & 11 & 23 \\
23 & Tanjungsari & 27 & \\
24 & Tambak Osowilangun & & \\
\hline \hline
\end{tabular}

\section{B. Model Development}

Variables - The variables are arranged based on the availability of the data as well as the earlier references to both books and articles.

TABLE II

VARIABLE AND PARAMETER

\begin{tabular}{|c|c|c|c|}
\hline Goals & Variables & Parameter & Sources \\
\hline $\begin{array}{l}\text { Knowing } \\
\text { road } \\
\text { characteristics }\end{array}$ & $\begin{array}{l}\text { Road } \\
\text { characteristics }\end{array}$ & $\begin{array}{l}\text { - Roadside } \\
\text { - The length of } \\
\text { the road } \\
\text { - The width of } \\
\text { the road }\end{array}$ & $\begin{array}{l}\text { Sukirman, } 1994 \text { [4] } \\
\text { MKJI } 1997 \text { [5] } \\
\text { PP No. } 342006 \text { [6] } \\
\text { UU No. } 222009 \text { [7] }\end{array}$ \\
\hline $\begin{array}{l}\text { Knowing } \\
\text { accidents } \\
\text { characteristics }\end{array}$ & $\begin{array}{l}\text { Accident } \\
\text { characteristics }\end{array}$ & $\begin{array}{l}\text { - Factors } \\
\text { causing the } \\
\text { accident } \\
\text { - Involvement } \\
\text { of accidents } \\
\text { - Type of } \\
\text { injury }\end{array}$ & $\begin{array}{l}\text { Warpani, } 2002[8] \\
\text { Sartono, } 1993[9] \\
\text { Suraji and Sulistio, } \\
2010[10] \\
\text { Khisty and Lall, } \\
2003[11] \\
\text { UU No } 222009 \text { [7] } \\
\text { PP No. } 431993[12]\end{array}$ \\
\hline \multirow[t]{3}{*}{$\begin{array}{l}\text { Knowing } \\
\text { rider's } \\
\text { characteristics }\end{array}$} & $\begin{array}{l}\text { Behaviour } \\
\text { characteristics }\end{array}$ & $\begin{array}{l}\text { - Driving } \\
\text { attitude } \\
\text { - Attitude } \\
\text { before driving }\end{array}$ & $\begin{array}{l}\text { Tamin, } 2000[13] \\
\text { Kartika, } 2009[14] \\
\text { Soekanto, } 2003[15] \\
\text { Suraji and Sulistio, } \\
2010[10]\end{array}$ \\
\hline & $\begin{array}{l}\text { Socio- } \\
\text { economic } \\
\text { characteristics }\end{array}$ & $\begin{array}{l}\text { - Age } \\
\text { - Work } \\
\text { - Gender } \\
\text { - Education } \\
\text { - Income } \\
\text { - Ownership of } \\
\text { motorcycles } \\
\text { - Number of } \\
\text { ownership } \\
\text { - Other } \\
\text { vehicles } \\
\text { owned }\end{array}$ & $\begin{array}{l}\text { Khisty and Lall, } \\
\text { B.K., } 2003 \text { [11] } \\
\text { UU No } 222009 \text { [7] } \\
\text { MKJI } 1997 \text { [5] }\end{array}$ \\
\hline & $\begin{array}{l}\text { Movement } \\
\text { characteristics }\end{array}$ & $\begin{array}{l}\text { - The } \\
\text { movement's } \\
\text { purpose and } \\
\text { objectives }\end{array}$ & \\
\hline
\end{tabular}

\begin{tabular}{|c|c|c|c|}
\hline Goals & Variables & Parameter & Sources \\
\hline $\begin{array}{l}\text { Create a } \\
\text { model of } \\
\text { motorcycle } \\
\text { accident } \\
\text { opportunity }\end{array}$ & $\begin{array}{l}\text { Motorcycle } \\
\text { user's } \\
\text { characteristics }\end{array}$ & $\begin{array}{l}\text { - Traveling } \\
\text { time } \\
\text { - Mileage } \\
\text { - Intensity of } \\
\text { use } \\
\text { - Start time of } \\
\text { activity } \\
\text { - Socio- } \\
\text { economic } \\
\text { characteristics } \\
\text { - Characteristic } \\
\text { s of } \\
\text { movement } \\
\text { - Behavioural } \\
\text { characteristics }\end{array}$ & $\begin{array}{l}\text { Suraji and Sulistio, } \\
2010[10]\end{array}$ \\
\hline
\end{tabular}

\section{Logistic regression}

In this study, accident models were developed to determine the probability of accidents involving predicted motorcycle riders through rider characteristics, accident characteristics, and geometric characteristics of existing roads. The technique used in analyzing the probability of accident occurrence is called logistic regression method. This method is used because it is an approach to making predictive models, where the predictions of dependent variables with dichotomy scale (nominal data scale with two categories). This method does not require conditions or assumptions that error variance (residual) is normally distributed, but follows logistics distribution. Logistic regression basic equations are as follows:

$P i=F\left(\beta o+\beta_{I} X_{I i}\right)=\frac{1}{1+e^{-z}}=\frac{1}{1+e^{-(\beta o+\beta 1 X 1 i)}}$

Where the next will be based on the formation of the logit model above then the model structure used in this study is as follows [10]:

$P_{(B A)}=\frac{1}{1+e^{-(\beta 0+\beta 1 X 1+\beta 0+\beta 2 X 2+\beta 0+\beta 3 X 3+\cdots \cdot)}}$

Where:

$\mathrm{P}(\mathrm{BA})=$ Opportunity occurrence of bicycle accident

$\mathrm{e} \quad=$ Natural Numbers (2.71828)

$\beta=$ Explanatory Variable Coefficients (predictor)

$\mathrm{X}=$ Explanatory Variable (predictor)

The stages in the logistic regression analysis are shown as in Figure 1 below. 


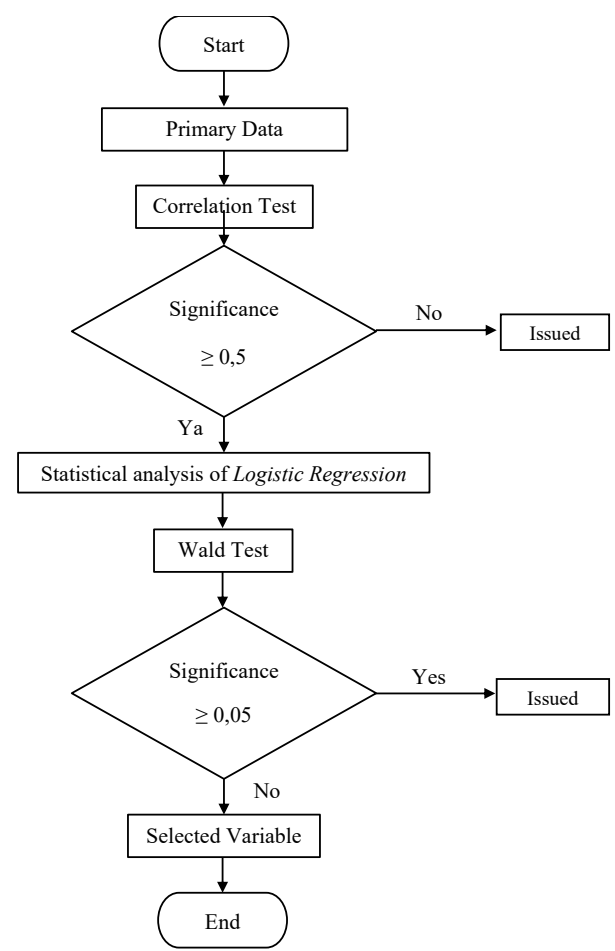

Fig. 1. The stages of logistic regression analysis

Model feasibility test - The feasibility of the regression model was assessed using Hosmer and Lemeshow's Goodness of Fit Test. If the statistical value of Hosmer and Lemeshow Goodness of fit is greater than 0.05 then the model can be concluded able to predict the observation value or it can be said the model is acceptable because according to the observation data.

In this study, the Overall Model Fit is used to assess the overall model by comparing the value between -2 Log Likelihood $(-2 \mathrm{LL})$ at the beginning (Block Number $=0$ ), where the model only includes constants with Log-Likelihood value $(-2 L L)$ at the end $($ Block Number $=1)$, where the model includes constants and independent variables. The existence of a value reduction between the initial 2LL (initial -2LL function) and the $-2 \mathrm{LL}$ value in the next step (-2LL final) indicates that the model hypothesized fit with the data.

The value of the coefficient of determination on the logistic regression model is shown by the value of Nagelkerke $R$ square. The value of Nagelkerke R Square can be interpreted as R Square value in multiple regressions. The purpose of this test is to know how big combination of independent variable that is socio-economic characteristic, movement, experience, and behavior of motorcycle rider able to explain variation of dependent variable that is possibility to have an accident.

To test this hypothesis then used the test of significance. The results of hypothesis testing is done by comparing the value of Omnibus Test of Model Coefficients is the value of chi square chances calculated with the value of alpha 5\% (0.05). The hypothesis of this study is the independent variables significantly influence simultaneously to the Opportunity of the accident.

Wald test or partial test is a test of the coefficient significance individually. The Wald test is the same as the $T$ test, according to M. Jainuri T test is one of the statistical tests used to test the truth or falsity of the null / nil hypothesis (H0) which states that between two randomly sampled mean samples from the same population is not present significant differences. Meanwhile, according to Hosmer and Lemeshow (1989) testing variables have done one by one using Wald test statistics. This test is done by comparing the best model, which is generated by the simultaneous test ( $G$ test) on the model without the free variable in the best model. The hypothesis to be tested is as follows:

1. H0 : $\beta \mathrm{j}=0$, meaning there is no influence between the $\mathbf{j}$ independent variable to the dependent variable.

2. $\mathrm{H} 1: \beta \mathrm{j} \neq 0$, meaning there is an independent variable influence on the dependent variable.

\section{RESUlTS AND DISCUSSION}

\section{A. Correlation test}

Pearson correlation or often called Product Moment Correlation (KPM) is a statistical test tool used to test the associative hypothesis (test relationship) two variables when the data scale interval or ratio. KPM was developed by Karl Pearson (Hasan, 1999). KPM is one form of parametric statistics because it tests data on an interval or ratio scale. The use of the Biserial Point Correlation formula is applied to test valid a test result in the form of the answer: true $=1$ and false $=0$. The largest $r$ value is +1 and the smallest $r$ is -1 . The value of $r=+1$ indicates a perfect positive relationship, whereas $r=-1$ denotes a perfectly negative relationship.

TABLE III

UNITS FOR MAGNETIC PROPERTIES

\begin{tabular}{lcc}
\hline \hline Explanatory Variables & Notation & $\begin{array}{c}\text { Correlation } \\
\text { Value }\end{array}$ \\
\hline Gender & X1 & $\mathbf{0 . 5 2 5}$ \\
Age & X2 & -0.367 \\
Education & X3 & $\mathbf{0 . 4 2 1}$ \\
Income & X4 & -0.203 \\
Profession & X5 & -0.147 \\
Motorcycles Ownership & X6 & 0.166 \\
Number of Motorcycle owned & X7 & -0.066 \\
Other Vehicles Owned & X8 & -0.057 \\
Goals and Purpose & X1 & 0.106 \\
Mileage & X11 & -0.066 \\
Travel Time & X12 & $\mathbf{0 . 5 6 0}$ \\
Bicycle Usage Frequency & X13 & 0.037 \\
Start Time of Motorcycles Usage & X14 & 0.015 \\
Knowledge of Motorcycles Lines & X15 & 0.344 \\
Is a Motorcycle Lane Needed? & X16 & -0.137 \\
Willingness to use Motorcycles Lines & X17 & 0.033 \\
If Income Rises, Do You Still Cycled? & X18 & 0.088 \\
If you have a Motorcycle, Do you Still Cycled? & X19 & -0.111 \\
The bicycle lane divider that wanted & X20 & - \\
Completion of a Rear-view mirror & X21 & 0.083 \\
The Horn Completeness & X22 & - \\
Main Lamp Completeness & X23 & 0.149 \\
Brake Lamp Completeness & X24 & 0.245 \\
Direction Lights Completeness & X25 & 0.174 \\
The speed measuring device Completeness & X26 & - \\
Exhaust Completeness & X27 & -0.010 \\
The depth of the tire groove & X28 & 0.092 \\
Completeness of light reflecting device & X29 & 0.110 \\
Checking Motorcycle Lights Conditions & X30 & 0.173 \\
Checking Motorcycle Brake Conditions & X31 & 0.046 \\
Checking Motorcycle Tire Conditions & & \\
& &
\end{tabular}




\begin{tabular}{|c|c|c|}
\hline Explanatory Variables & Notation & $\begin{array}{l}\text { Correlation } \\
\text { Value }\end{array}$ \\
\hline Checking Motorcycle Chain Conditions & X32 & 0.086 \\
\hline Checking the Battery Condition & X33 & 0.102 \\
\hline Checking the Lubricating Oil & X34 & -0.001 \\
\hline Check the Rear-view Mirror & $\mathrm{X} 35$ & -0.047 \\
\hline Wearing a Helmet & $\mathrm{X} 36$ & 0.014 \\
\hline Wearing Gloves & X37 & 0.044 \\
\hline Wearing Knee Shield & $\mathrm{X} 38$ & 0.070 \\
\hline Wearing an Elbow Shield & X39 & -0.146 \\
\hline Wear Bright / Sunny Clothes & $\mathrm{X} 40$ & -0.012 \\
\hline Together & $\mathrm{X} 41$ & 0.051 \\
\hline Walking In Group & $\mathrm{X} 42$ & 0.267 \\
\hline Frolic & X43 & 0.111 \\
\hline Break through the Red Light & X44 & 0.050 \\
\hline Bringing Goods / Loads in Large Quantities & $\mathrm{X} 45$ & 0.060 \\
\hline Overtaking From Right & $\mathrm{X} 46$ & 0.531 \\
\hline Give Signal When Turning Right & $\mathrm{X} 47$ & 0.045 \\
\hline Traveling When It Rains & $\mathrm{X} 48$ & 0.076 \\
\hline $\begin{array}{l}\text { How Many Times Have Motorcycle } \\
\text { Accidents? }\end{array}$ & X49 & -0.022 \\
\hline $\begin{array}{l}\text { How Many Times Experienced Injuries Due to } \\
\text { Motorcycle Accidents }\end{array}$ & $\mathrm{X} 50$ & 0.150 \\
\hline Costs Spent For Accident Injury Care & $\mathrm{X} 51$ & -0.204 \\
\hline Costs Spent For Motorcycle Repair & $\mathrm{X} 52$ & -0.317 \\
\hline Time of Accident & $\mathrm{X} 53$ & -0.297 \\
\hline Exact Time of Accident & $\mathrm{X} 54$ & -0.539 \\
\hline Causes of Accidents & $\mathrm{X} 55$ & -0.485 \\
\hline $\begin{array}{l}\text { Has the Government Attended the Safety of } \\
\text { Motorcycle Riders? }\end{array}$ & $\mathrm{X} 56$ & 0.025 \\
\hline $\begin{array}{l}\text { Are Motor Vehicle Drivers Careful about the } \\
\text { Safety of Motorcycle Riders? }\end{array}$ & $\mathrm{X} 57$ & -0.021 \\
\hline $\begin{array}{l}\text { Do You Feel Displaced By Motor Vehicle } \\
\text { Drivers When You're On The Road? }\end{array}$ & $\mathrm{X} 58$ & -0.028 \\
\hline $\begin{array}{l}\text { Are Special Policies / Regulations Required To } \\
\text { Protect Motorcycle Riders? }\end{array}$ & X59 & 0.112 \\
\hline $\begin{array}{l}\text { Have you ever experienced an accident while } \\
\text { cycling? }\end{array}$ & X60 & 1.000 \\
\hline
\end{tabular}

\section{B. Opportunity accidents based on socio-economic characteristics}

In this characteristic there are eight explanatory variables tested for further model of probability of accident and analyzed. The analysis is by searching for explanatory variables that affect response variables. According to the correlation test of the explanatory variables and response variables in socio-economic characteristics it is concluded that the variables X2 (age), X4 (Earnings), X5 (work), X6 (bike ownership), X7 (number of bicycle ownership), and X8 (other vehicles owned) is eliminated because it has a correlation value smaller than 0.4. And there are two explanatory variables that proved to be related to the dependent variable $\mathrm{X} 1$ (sex) and X3 (education).

TABLE IV

LOGISTIC REGRESSION COEFFICIENT TEST RESULTS ON SOCIO-ECONOMIC CHARACTERISTICS

\begin{tabular}{lcccccc}
\hline \hline $\begin{array}{l}\text { Independent } \\
\text { variable }\end{array}$ & $\mathrm{B}$ & S.E. & Wald & df & Sig. & $\begin{array}{c}\text { Exp } \\
\text { (B) }\end{array}$ \\
\hline X1 & 0.930 & 0.192 & 23.45 & 1.000 & 0.000 & 2.534 \\
X3 & 0.518 & 0.187 & 7.679 & 1.000 & 0.006 & 1.678 \\
Constant & -4.991 & 0.851 & 34.42 & 1.000 & 0.000 & 0.007 \\
\hline \hline
\end{tabular}

So the regression equation is:
$Y=-4.991+0.930 X 1+0.518 X 3$

Odd Ratio gender of motorcyclists in driving of $\mathrm{e}^{0.930}=$ 2.5345 , probability of occurrence of rider chance of accident 2.5345 times, the value is bigger than one so chance of accidents will increase because of gender in motorcycle riding. While the Odd Ratio of motorcyclist gender in driving is equal to $\mathrm{e}^{0.518}=1.679$, the probability of occurrence is 1.679 times, the value is greater than one so the chance of accidents will increase due to gender in motorcycle riding.

\section{Opportunity accidents based on movement characteristics}

In the characteristics of bicycle users movement there are five explanatory variables tested against response variables to model accident probability models and then analyzed. According to the correlation test that has been done on the explanatory variable and the response variable in the movement characteristics, it is found that the $\mathrm{X} 9$ variable (motion intent), X10 (travel distance), X11 (time of traveling), X13 (activity start time) are eliminated has a correlation value smaller than 0.5 . And there is one explanatory variable that proved to be related i.e. and X12 (frequency of motorcycle use).

TABLE V

THE RESULTS OF LOGISTIC REGRESSION COEFFICIENT TEST ON THE CHARACTERISTICS OF MOVEMENT

\begin{tabular}{lcccccc}
\hline \hline $\begin{array}{c}\text { Independent } \\
\text { variable }\end{array}$ & $\mathrm{B}$ & S.E. & Wald & df & Sig. & $\begin{array}{c}\text { Exp } \\
\text { (B) }\end{array}$ \\
\hline X12 & 3.386 & 0.550 & 37.97 & 1.000 & 0.000 & 29.54 \\
Constant & -4.207 & 0.633 & 44.23 & 1.000 & 0.000 & 0.015 \\
\hline \hline
\end{tabular}

So the regression equation is:

$Y=-4.207+3.386 X 12$

Odd The frequency ratio of motorcycle use in driving is equal to $\mathrm{e}^{3.386}=29.547$, the probability of occurrence of rider chance of accident is equal to 29.547 times, the value is bigger than one so the chance of accidents will increase along with the increasing frequency of motorcycle usage.

\section{Accidental opportunities based on behavioral characteristics}

There are twelve explanatory variables on the characteristics of bicycle user behavior tested to serve as a chance probability model. According to the correlation test that has been done on the explanatory variable and the response variable in the movement characteristics it is found that X46 (preceding from the left), has an effect on the chance of the accident.

TABLE VI

THE RESULT OF LOGISTIC REGRESSION COEFFICIENT TEST ON BEHAVIORAL CHARACTERISTIC

\begin{tabular}{lcccccc}
\hline $\begin{array}{l}\text { Independent } \\
\text { variable }\end{array}$ & $\mathrm{B}$ & S.E. & Wald & df & Sig. & $\begin{array}{c}\text { Exp } \\
\text { (B) }\end{array}$ \\
\hline X46 & 2.412 & 0.389 & 38.458 & 1.000 & 0.000 & 11.160 \\
Constant & -4.504 & 0.747 & 36.314 & 1.000 & 0.000 & 0.011 \\
\hline \hline
\end{tabular}


So the regression equation is:

$Y=-4.504+2.412 X 46$

Odd Ratio motorcyclist behavior proceeds from the left in driving of $\mathrm{e}^{2.412}=11.156$, probability of occurrence rider chance of accident 11.156 times, the value is bigger than one so chance of accidents will increase because precedes from left side in motorcycle riding.

\section{E. Accidents Opportunity by Type of Experience}

In the characteristics of the movement of bicycle users there are seven explanatory variables tested against response variables to model accidental opportunities and then analyzed. According to the correlation test that has been done on the explanatory variable and the response variable in the movement characteristics, it is found that the variables X53 (accident time) and X55 (cause of accidents) have an effect on the chance of the accident.

TABLE VII

THE RESULT OF LOGISTIC REGRESSION COEFFICIENT TEST ON EXPERIENCE CHARACTERISTIC

\begin{tabular}{lcccccc}
\hline \hline $\begin{array}{l}\text { Independent } \\
\text { variable }\end{array}$ & $\mathrm{B}$ & S.E. & Wald & df & Sig. & $\begin{array}{c}\text { Exp } \\
\text { (B) }\end{array}$ \\
\hline X54 & -0.988 & 0.166 & 35.505 & 1.000 & 0.000 & 0.372 \\
X55 & 3.586 & 0.107 & 11.139 & 1.000 & 0.001 & 0.699 \\
Constant & 3.662 & 0.565 & 42.073 & 1.000 & 0.000 & 38.949 \\
\hline \hline
\end{tabular}

So the regression equation is:

$Y=3.662-0.988 X 54+3.586 X 55$

Odd Ratio of time in motorbike driving equal to $\mathrm{e}^{-0.988}=$ 0.3723 , probability of occurrence of rider chance of accident will decrease equal to 0.3723 times, the value is less than one so chance of accidents will decrease associated with existence of special lane for cyclist motorcycle.

Odd Ratio self-fault motorcyclists in effect on the occurrence of accidents of $\mathrm{e}^{3.586}=0.3609$, the probability of occurrence of rider chance of an accident of 0.3609 times, the value is smaller than one so the probability of accidents will decrease due to self-fault of cyclists motorcycle.

\section{CONCLUSIONS AND SUGGESTIONS}

Model of motorcycle accident opportunity in Surabaya city that produced is as follows:

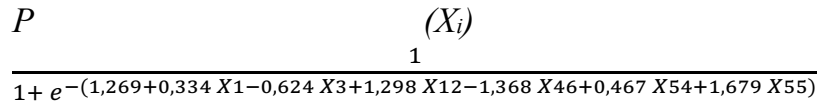

The chance model of accidents involving motorcyclists in the city of Surabaya is influenced by the gender and educational background of the rider. In addition, the behavior of motorcyclists that precede the vehicle from the left also provides great opportunities for accidents. For further research, this model of motorcycle accident chance can be developed by developing more identifiable variables, either by human (rider), road, or the vehicle used by itself.

\section{REFERENCES}

[1] Badan Pusat Statistik. "Jumlah Penduduk Provinsi Jawa Timur.' https://jatim.bps.go.id/ accessed 27 September 2017.

[2] Badan Pusat Statistik. "Kota Surabaya Dalam Angka 2017," Surabaya, 2018.

[3] R. Riyantama, and R.F.N. Kholis, "Model Peluang Kecelakaan Yang Melibatkan Pengendara Sepeda Motor Di Kota Surabaya," Bachelor thesis, unpublished, Malang, Brawijaya University, 2018.

[4] S. Sukirman, Dasar-Dasar Perencanaan Geometrik Jalan, Bandung, Nova Publisher, 1999.

[5] Departemen Pekerjaan Umum, Manual Kapasitas Jalan Indonesia, Jakarta, Direktorat Jenderal Bina Marga, 1997.

[6] Republik Indonesia, Peraturan Pemerintah Republik Indonesia Nomor 34 Tahun 2006 tentang Jalan, Jakarta, 2006.

[7] Republik Indonesia, Undang-Undang Republik Indonesia Nomor 22 Tahun 2009 tentang Lalu Lintas dan Angkutan, Jakarta, 2009.

[8] Warpani, Pengelolaan Lalu Lintas dan Angkutan Jalan, Bandung, Bandung Institute of Technology, 1999.

[9] W. Sartono, "Penelitian Daerah Rawan Kecelakaan Lalu Lintas pada Ruas Jalan Kupang-Atambua di Provinsi Nusa Tenggara Timur," Media Teknik, Vol. 15, No 1, Yogyakarta, Gadjah Mada University, 1993.

[10] A. Suraji, and H. Sulistio, "Model Kecelakaan Sepeda Motor Pada Suatu Ruas Jalan," Jurnal Transportasi, Forum Studi Transportasi Antar Perguruan Tinggi, Vol. 10, No. 1, April 2010, 53 - 64. Bandung, Parahiyangan University, 2010.

[11] C. J. Khristy, and B.K. Lall, Dasar-Dasar Rekayasa Transportasi. Bandung, Erlangga Publisher, 2003.

[12] Republik Indonesia, Peraturan Pemerintah Republik Indonesia Nomor 43 Tahun 1993 tentang Prasarana dan Lalu Lintas, Jakarta, 1993.

[13] O.Z. Tamin, Perencanaan dan Pemodelan Transportasi. Bandung, ITB Publisher, 2000

[14] M. Kartika, "Analisis Faktor Penyebab Kecelakaan Lalu Lintas Pada Pengendara Sepeda Motor Di Wilayah Depok," Depok, University of Indonesia, 2009.

[15] S. Soekanto, Memperkenalkan Sosiologi, Jakarta, 2003. 